\title{
Supplementation with lipid sources alters the ruminal fermentation and duodenal flow of fatty acids in grazing Nellore steers
}

\author{
Isabela Pena Carvalho de Carvalho ${ }^{\mathrm{a}}$, Giovani Fiorentini ${ }^{\mathrm{a}}$, \\ Pablo de Souza Castagnino ${ }^{\mathrm{a}, *}$, Raphael Barbetta de Jesus ${ }^{\mathrm{a}}$, Juliana Duarte Messana ${ }^{\mathrm{a}}$, \\ Yury Tatiana Granja-Salcedo ${ }^{\text {, }}$ Edenio Detmann ${ }^{\mathrm{b}, \mathrm{c}}$, Jagadish Padmanabha ${ }^{\mathrm{d}}$, \\ Christopher S. McSweeney ${ }^{\mathrm{a}, \mathrm{b}, \mathrm{c}, \mathrm{d}}$, Telma Teresinha Berchielli ${ }^{\mathrm{a}, \mathrm{c}}$ \\ ${ }^{a}$ Faculdade de Ciências Agrárias e Veterinárias, Universidade Estadual Paulista (Unesp), Via de Acesso Professor Paulo Donato Castellane, km 5, \\ Rural, Jaboticabal, São Paulo 14884-900, CEP, Brazil \\ b Department of Animal Science, Universidade Federal de Vicosa, Viçosa,Minas Gerais 36570-000, Brazil \\ ${ }^{\mathrm{c}}$ Department of Animal Science, INCT/CA-UFV, Campus Universitário, Av. Peter Henry Rolfs s/n, Viçosa, Minas Gerais 36570-000, CEP, Brazil \\ ${ }^{\mathrm{d}}$ CSIRO Animal, Food and Health Sciences, St Lucia 4067, QLD, Australia
}

\section{A R T I C L E I N F O}

\section{Keywords:}

Biohydrogenation

Brachiaria brizantha

Linseed

Microbial population

Palm oil

\begin{abstract}
A B S T R A C T
Lipid supplementation may adversely affect rumen fermentation, microbial abundance, nutrient utilization and the duodenal flow of fatty acids (FA). In a $5 \times 5$ Latin square design, 10 Nellore steers with ruminal and duodenal cannulas $(292 \pm 28 \mathrm{~kg} \mathrm{BW})$ were fed one of the five following dietary lipid sources in the concentrate, as follow: (1) no additional fat (WF); (2) palm oil (PO) derived from the Palmaceae plant Orbignya oleifera; (3) linseed oil (LO); (4) protected fat (PF); and (5) whole soybeans (WS). The dry matter intake (DMI) was greater for the animals supplemented with WF than for those supplemented with PO, PF, and WS. The DM digestibility was $11 \%$ greater for the animals in the WF group than for those in the PO group. The animals in the PO group had greater duodenal flows of capric (C10:0), lauric (C12:0) and myristic (C14:0) saturated fatty acids (SFA) than did animals in the other groups. The amount of flows of vaccenic acid and total unsaturated acids (UFA) was greater with LO supplementation. The unsaturated fatty acid (UFA) biohydrogenation ratio was greater in the animals supplemented with WS than in those supplemented with PO, LO, and PF. The acetate: propionate ratio was lower in the animals supplemented with $\mathrm{PO}$ and LO, at 2.9 and 3.0, respectively. The ruminal flow of particles and rate of fiber degradation were lower with PO supplementation. The proportion of archaea was reduced with the inclusion of PO, LO and PF. PO supplementation resulted in lower total apparent NDF digestibility than did WF, PF, and WS supplementation. Therefore, LO, PF and WS can be used as dietary supplements for grazing cattle without impairing fermentation. The inclusion of PO in the diets of grazing cattle may reduce the number of methanogens and alter fiber utilization.
\end{abstract}

\footnotetext{
Abbreviations: ADF, acid detergent fiber; ADFom, ADF expressed exclusive of residual ash; aNDF, NDF without sodium sulfite, with alpha amylase and corrected for residual ash; BUFA, biohydrogenation of unsaturated fatty acids; $\mathrm{CP}$, crude protein; DM, dry matter; DMI, dry matter intake; EE, ether extract; iADF, indigestible acid detergent fiber; LO, linseed oil; BW, body weight; MM, mineral matter; NDF, neutral detergent fiber with $\alpha$-amylase* without sodium sulfite and expressed inclusive of residual ash; NDFom, NDF assayed with a heat-stable amylase and expressed exclusive of residual ash; OM, organic matter; PF, protected fat; PO, palm oil; SFAs, saturated fatty acids; UFA, unsaturated fatty acids; VFA, volatile fatty acids; WF, without additional fat; WS, whole soybeans

* Corresponding author. Fax: +55 1632092682.

E-mail address: pablocastagnino@hotmail.com (P.d.S. Castagnino).
} 


\section{Introduction}

Fat supplementation in pasture-based systems may increase dietary energy density and ruminant performance (Hess et al., 2008; Santana et al., 2015). The use of lipid sources, such as soybean oil, may improve the fatty acid profiles of meat and fat (Ludden et al., 2009), and reduce enteric methane emissions (Martin et al., 2010; Grainger and Beauchemin, 2011). However, the inclusion of FA has adverse effects on ruminal fermentation (Maia et al., 2007; Gudla et al., 2012). The negative effects of dietary FA on fiber degradation and DMI are associated with the level and source of supplemental fat added and the basal diet (Jenkins, 1993; Kucuk et al., 2004; Manso et al., 2006; Shingfield et al., 2010).

Supplementing beef cattle with feed additives and lipids sources with different fatty acids contents can reduce methane emissions by increasing the molar proportion of propionate, which provides a $\mathrm{H}_{2}$ sink that reduces uptake of $\mathrm{H}_{2}$ by archaea for methane production (Knapp et al., 2014). The inclusion of lipids leads to a 5.6\% reduction in methane production per percentage unit of lipid added to the diet (Beauchemin et al., 2008).

Several products with different fatty acid profiles have been used as lipid sources in ruminant diets (Duckett and Gillis, 2010), including vegetable oil, oil seeds and calcium soaps of palmitic acids. The effect of lipids on ruminal fermentation can be attributed to the inhibitory effect of fatty acids on some microbial species (Jenkins, 1993), which modifies the ruminal system and alters microbial diversity.

In tropical countries, such as Brazil, most meat production relies on pasture-based systems, and the majority of herds are composed of Bos indicus breeds. However, most studies have evaluated the effects of the above mentioned lipid sources on digestibility and microbial diversity in studies on Bos taurus with limited variation in dietary fatty acid composition (Montgomery et al., 2008; Yang et al., 2009; Otaru et al., 2011; Wanapat et al., 2011). However, to date, there is no information of rumen microbial diversity studies in cattle grazing tropical pasture supplemented with lipids. We hypothesized that lipid sources that are protected, such as WS and PF or more saturated, such as PO, would cause less disturbance to ruminal fermentation. LO supplementation would increase the flow of UFA to the duodenum and decrease intake due to impairment of rumen fermentation and animal metabolism. Therefore, this study aimed to evaluate the effects of lipid sources with different FA profiles on the nutrient digestibility and ruminal fermentation of Nellore cattle grazing tropical pastures.

\section{Material and Methods}

This study was conducted in accordance with the Brazilian College of Animal Experimentation (COBEA - Colégio Brasileiro de Experimentação Animal) and it was approved by the Ethics, Bioethics, and Animal Welfare Committee (CEBEA; protocol number 012799).

\subsection{Animals and Feed Management}

Ten Nellore steers fitted with rumen and duodenal cannula (average BW $292 \pm 28 \mathrm{~kg}$ ) were randomly assigned to a double $5 \times 5$ Latin square design. The treatments consisted of supplemental lipid sources in concentrate, as follows: (1) no additional fat (WF); (2) palm oil (PO) derived from the Palmaceae plant Orbignya oleifera, which has a lipid profile rich in medium-chain FA (C12:0 and C14:0); (3) linseed oil (LO); (4) protected fat (PF) (Lactoplus, Dalquim group, Itajaí, Santa Catarina, Brazil); and (5) whole soybeans (WS). Nellore steers were kept in 1.9 ha paddocks of Brachiaria brizantha "Xaraés" pasture under continuous stocking, and the canopy was maintained at height of $35 \mathrm{~cm}$. The feed ingredients and the chemical compositions of the concentrate mixtures and forage are shown in Table 1 . The supplements were infused into the rumen twice per day at 07:00 $\mathrm{h}$ and $12: 00 \mathrm{~h}$ at $10 \mathrm{~g} / \mathrm{kg} \mathrm{BW}$ per day for 19 day.

\subsection{Sampling and Chemical Analysis}

Individual feed intake was estimated using the two-markers method, which involved the use of LIPE ${ }^{\varpi}$ and indigestible acid detergent fiber (iADF) to estimate the excretion of fecal matter (as dry weight) and forage intake, respectively (Santos et al., 2011). Fecal DM excretion was determined using purified and enriched lignin (LIPE ${ }^{\varpi}$ ). The animals received the marker (infused into the rumen via ruminal cannula) daily for 6 days beginning on day 13. After 3 days of adaptation, fecal samples were collected from the rectum at $07: 00,11: 00$, and 16:00 h on days 17, 18, and 19. Fecal samples obtained from each animal on each collection day were individually used to determine the LIPE ${ }^{\oplus}$ concentrations. The rates of individual forage intake were estimated using an internal marker, iADF. Fecal iADF in the forage and supplement samples was quantified following a $264 \mathrm{~h}$ ruminal incubation of the samples as described by Casali et al. (2008). The acid detergent fiber (ADF) was determined based on the procedures described by Mertens (2002) using an ANKOM200/220 Fiber Analyzer (ANKOM Technology Corp., Fairport, NY, USA). The iADF was determined by weighing the bags with a digital scale after drying in an oven, first at $55^{\circ} \mathrm{C}$ for $72 \mathrm{~h}$ and then at $105{ }^{\circ} \mathrm{C}$ for $12 \mathrm{~h}$. The residue was considered the iADF.

Duodenal samples were collected over 2 days at $6 \mathrm{~h}$ intervals. Sample collection was delayed on the second day to ensure that every $3 \mathrm{~h}$ within a $24 \mathrm{~h}$ period was fully represented (Oliveira et al., 2007). Samples were kept at $-20^{\circ} \mathrm{C}$, and at the end of the period, samples from each animal were pooled to create one sample per treatment per period. iADF was used as an indicator of daily DM flow in the duodenum (Harvatine and Allen, 2006), and it was determined via an in situ methodology after $264 \mathrm{~h}$ (Casali et al., 2008) using incubated ground feed and fecal and duodenal digesta samples (Wiley Mill $2 \mathrm{~mm}$ screen) and was analyzed with an 
Table 1

Ingredients and chemical compositions of the dietary treatments and forage.

\begin{tabular}{|c|c|c|c|c|c|c|}
\hline \multirow[b]{2}{*}{ Ingredients ( $\mathrm{g} / \mathrm{kg} \mathrm{DM})$} & \multicolumn{5}{|c|}{ Supplement $^{\mathrm{a}}$} & \multirow[t]{2}{*}{ Forage } \\
\hline & WF & $\mathrm{PO}$ & LO & $\mathrm{PF}$ & WS & \\
\hline Ground corn & 755 & 655 & 655 & 645 & 570 & - \\
\hline Soybean meal & 200 & 220 & 220 & 220 & 0.00 & - \\
\hline Palm oil & 0.00 & 80.0 & 0.00 & 0.00 & 0.00 & - \\
\hline Linseed oil & 0.00 & 0.00 & 80.0 & 0.00 & 0.00 & - \\
\hline Protected fat & 0.00 & 0.00 & 0.00 & 90.0 & 0.00 & - \\
\hline Soybean & 0.00 & 0.00 & 0.00 & 00.0 & 400 & - \\
\hline Urea & 15.0 & 15.0 & 15.0 & 15.0 & 0.00 & - \\
\hline Minerals $^{\mathrm{b}}$ & 30.0 & 30.0 & 30.0 & 30.0 & 30.00 & - \\
\hline Nutrients & - & - & - & - & - & - \\
\hline $\mathrm{DM}, \mathrm{g} / \mathrm{kg}$ & 880 & 890 & 890 & 890 & 890 & 506 \\
\hline $\mathrm{OM}, \mathrm{g} / \mathrm{kg} \mathrm{DM}$ & 944 & 942 & 943 & 920 & 937 & 909 \\
\hline $\mathrm{CP}, \mathrm{g} / \mathrm{kg} \mathrm{DM}$ & 220 & 219 & 213 & 224 & 224 & 125 \\
\hline $\mathrm{EE}, \mathrm{g} / \mathrm{kg} \mathrm{DM}$ & 41.0 & 104 & 93.8 & 96.7 & 116 & 33.5 \\
\hline aNDFom, $\mathrm{g} / \mathrm{kg}$ DM & 126 & 118 & 149 & 118 & 129 & 580 \\
\hline $\mathrm{ME}, \mathrm{Mcal} / \mathrm{kg} \mathrm{DM}^{\mathrm{c}}$ & 3.32 & 3.56 & 3.48 & 3.44 & 3.46 & 1.94 \\
\hline Fatty acid profile, $\mathrm{g} / 100 \mathrm{~g}$ of total fatty acids & - & - & - & - & - & - \\
\hline C6:0 (caproic) & 0.00 & 0.11 & 0.00 & 2.70 & 0.00 & 0.00 \\
\hline C10:0 (capric) & 0.00 & 2.43 & 0.00 & 0.00 & 0.00 & 0.39 \\
\hline C12:0 (lauric) & 0.00 & 37.7 & 0.10 & 4.91 & 0.00 & 0.69 \\
\hline C14:0 (miristic) & 0.14 & 12.6 & 0.04 & 0.04 & 0.02 & 1.46 \\
\hline C15:0 (pentadecanoic) & 0.00 & 0.00 & 0.00 & 0.00 & 5.87 & 0.71 \\
\hline C16:0 (palmitic) & 10.4 & 8.98 & 7.18 & 2.79 & 2.27 & 37.9 \\
\hline C18:0 (stearic) & 3.7 & 2.21 & 4.41 & 14.8 & 6.21 & 8.17 \\
\hline C18:1 n9,c (Oleic) & 21.8 & 17.1 & 20.6 & 44.9 & 23.6 & 37.9 \\
\hline C18:2 n6,c (linoleic) & 48.9 & 14.9 & 23.0 & 25.8 & 54.4 & 9.7 \\
\hline C18:3 n3 (linolenic) & 4.8 & 1.27 & 41.9 & 1.27 & 5.34 & 1.05 \\
\hline SFAs & 46.3 & 72.6 & 20.4 & 33.9 & 21.5 & 51.0 \\
\hline UFAs & 53.7 & 27.4 & 79.6 & 66.1 & 78.5 & 39.3 \\
\hline
\end{tabular}

${ }^{\text {a } W F}$ - without additional fat; PO - palm oil; LO - linseed oil; PF - protected fat (LactoPlus ${ }^{\star 0}$ ); WS - whole soybeans.

b Mineral composition of supplements (Ca, 160 g; P, 40 g; Mg, 5 g; S, 40 g; Na, 160 g; Cu, 945 mg; Mn, 730 mg; Zn, 3500 mg; I, 70 mg; Co, 56 mg; Se, 18 mg; F(máx) $400 \mathrm{mg})$.

${ }^{c}$ Metabolizable energy by NRC, 1996.

ANKOM200/220 Fiber Analyzer (ANKOM Technology Corp., Fairport, NY, USA). Duodenal DM flow was calculated according to the following equation:

Duodenal DM flow $=([$ fecal DM $\times \mathrm{g} / \mathrm{kg}$ indigestible ADF in fecal DM $] / \mathrm{g} / \mathrm{kg}$ indigestible NDF in duodenal DM $)$.

Forage samples were collected during each period by the hand-plucking technique (Johnson, 1978). Forage, concentrate, duodenal digesta and fecal samples were oven-dried at $55{ }^{\circ} \mathrm{C}$ for $72 \mathrm{~h}$ and ground by passage through a Wiley Mill $1 \mathrm{~mm}$ screen. Procedures described by the Association of Official Analytical Chemists (AOAC, 1990) were used to determine the amounts of dry matter (DM, 934.01), organic matter (OM, 942.05) and acid ether extract (EE, 954.02). The crude protein (N x 6.25) was determined according to the Dumas combustion method using a Leco ${ }^{\circledast}$ Nitrogen Determinator, model FP-528 (Leco Corp., St. Joseph, MI, USA).

Neutral detergent fiber (aNDFom) analyses were performed without sodium sulfite and with alpha amylase, and the data were corrected for residual ash. The aNDFom was also corrected for residual ash.

Fatty acids were extracted according to the method described by Folch et al. (1957), and methylation was assessed as described by Kramer et al. (1997) using $2 \mathrm{~mL}$ of $0.5 \mathrm{M}$ sodium methoxide $\left(10 \mathrm{~min}\right.$ at $\left.50{ }^{\circ} \mathrm{C}\right)$, followed by the addition of methanoic $\mathrm{HCl}(10 \mathrm{~min}$ at $80^{\circ} \mathrm{C}$ ). Fatty acids were quantified using a GC 20-10 gas chromatograph (Shimadzu Corp., Kyoto, Japan; $100 \mathrm{~m} \times 0.20 \mathrm{~mm}$ i.d. with $0.20 \mu \mathrm{m}$ film thickness; Supelco, Bellefonte, PA, USA). Hydrogen was used as the carrier gas at a flow rate of $1.8 \mathrm{~mL} / \mathrm{min}$. The initial oven temperature was $70{ }^{\circ} \mathrm{C}$, and was increased by $13{ }^{\circ} \mathrm{C} / \mathrm{min}$ to $175^{\circ} \mathrm{C}$, at which point it was maintained for 27 min. The temperature was then increased by $4{ }^{\circ} \mathrm{C} / \mathrm{min}$ to $215^{\circ} \mathrm{C}$, was then maintained for $9 \mathrm{~min}$, followed by another increase of $7{ }^{\circ} \mathrm{C} / \mathrm{min}$ to $230{ }^{\circ} \mathrm{C}$, and holding for $5 \mathrm{~min}$. The temperature of the injector was $250{ }^{\circ} \mathrm{C}$, and that of the detector was $300{ }^{\circ} \mathrm{C}$. The biohydrogenation of unsaturated fatty acids (BUFAs) was calculated as described by Aldrich et al. (1995) as follows: the biohydrogenation of total unsaturated C18 fatty acids (BUFA g/100 g) = 100 - $100 \times$ (total duodenal concentration of unsaturated C18/total C18 in duodenal digesta)/(total unsaturated C18 intake/total C18 intake).

Ruminal contents were sampled on day 19 of each period to determine the $\mathrm{pH}$ values and the concentrations of VFAs and ammonia nitrogen (NH-N). Samples were collected at 07:00, 10:00, 13:00, 16:00, 19:00, and 22:00 h, and pH was measured after the contents were filtered. Two $20 \mathrm{~mL}$ aliquots were stored at $-10{ }^{\circ} \mathrm{C}$ and were later used to determine the $\mathrm{NH}-\mathrm{N}$ concentration as describing by Fenner (1965), adapted for use in Kjeldahl distillation. The VFA concentrations were measured using a gas chromatograph (GC2014, Shimadzu Corporation, Kyoto, Japan) with an HP-INNOWax capillary column $(30 \mathrm{~m} \times 0.32 \mathrm{~mm}$; $0.50 \mu \mathrm{m}$ film thickness; Agilent Technologies, CO, USA) at an initial temperature of $80^{\circ} \mathrm{C}$ which was increased by $20^{\circ} \mathrm{C} / \mathrm{min}$ until 
a final temperature of $240{ }^{\circ} \mathrm{C}$ was reached.

\subsection{Kinetics of Fibrous Particles and NDF Degradation Profile}

The transit kinetics of fibrous particles was evaluated on day 11-16 of each period using a pulse dose of fiber mordant ytterbium (Ellis et al., 1994). Hand-plucked pasture samples were used for mordant production according to the procedures described by Vega et al. (1998). On the 4th day of each experimental period at 07:00 h, approximately $50 \mathrm{~g}$ of fiber mordant were placed into the rumens of the animals. Fresh fecal grab samples were collected at $0,3,6,9,12,24,36,48,72,96$, and 120 h after marker administration. The samples were oven-dried $\left(60{ }^{\circ} \mathrm{C} / 72 \mathrm{~h}\right)$ and processed in a Willey Mill $(1 \mathrm{~mm})$. At the same time as the transit evaluation, in situ incubation was carried out to estimate the rumen degradation parameters of the NDF. Hand-plucked pasture samples were processed in a Willey Mill $(1 \mathrm{~mm})$ and placed in nonwoven textile $\left(100 \mathrm{~g} / \mathrm{m}^{2}\right)$ bags at $20 \mathrm{mg} \mathrm{DM} / \mathrm{cm}^{2}$ of bag surface. Bags containing $2 \mathrm{~g}$ of sample were incubated in duplicate for each time point in the rumen. The following incubation times were used: $0,3,6,9,12,18,24,36,48,72,96$, and $120 \mathrm{~h}$. After incubation, the bags were cleaned with tap water and oven-dried $\left(55^{\circ} \mathrm{C}\right)$. The residual NDF content was evaluated without sodium sulfite, with alpha amylase and expressed inclusive of residual ash according to the methodology of Mertens (2002).

Fecal samples used to evaluate the transit kinetics parameters were analyzed for DM content (AOAC, 1995; 934.01) and ytterbium (Vega et al., 1998). The parameters used to evaluate transit kinetics were estimated via adjustment of a gamma-2 time-dependent model of ytterbium excretion profiles (Ellis et al., 1994) as follows:

$$
C_{t}=Z \times(t-\tau) \times \gamma \times \exp [-\gamma \times(t-\tau)]
$$

where $C_{t}$ is the fecal concentration of ytterbium (ppm) at time " $t$ ", $t$ is the time after marker administration (h), $\gamma$ is the timedependent rate parameter related to the rumen flow of fibrous particles $\left(\mathrm{h}^{-1}\right), \mathrm{Z}$ is a parameter without biological meaning (ppm $\times$ $\mathrm{h}$ ), and $\tau$ is the time of intestinal transit (h). Estimates of the mean retention time in the rumen and that in the entire gastrointestinal tract were obtained according to Eqs. (2) and (3) (Ellis et al., 1994) as follows:

$$
\begin{aligned}
& \text { MRTR }=\frac{2}{\gamma} \\
& M R T T=M R T R+\tau
\end{aligned}
$$

where MRTR is the mean retention time in the rumen (h), and MRTT is the mean retention time in the gastrointestinal tract (h). The NDF degradation profiles were evaluated according to the logistic model described by Van Milgen et al. (1991) as follows:

$$
R_{t}=B \times(1+\lambda \times t) \times \exp (-\lambda \times t)+U
$$

where $R_{t}$ is the non-degraded NDF residue at time " $t$ " (\%), B is the potentially degradable fraction (\%), $U$ is the non-degradable fraction (\%), and $\lambda$ is the common rate of latency and degradation $\left(\mathrm{h}^{-1}\right)$. The discrete lag estimates were obtained according to the equation described by Vieira et al. (1997) as follows:

$$
L A G=\frac{R(0)-R\left(t_{i}\right)}{R^{\prime}\left(t_{i}\right)}+t_{i}
$$

where LAG is the discrete lag $(\mathrm{h}), \mathrm{R}(0)$ is the non-degraded NDF residue at $t=0, \mathrm{R}\left(\mathrm{t}_{i}\right)$ is the non-degraded NDF residue at the inflection point of the degradation profile (\%), $\mathrm{R}^{\prime}\left(\mathrm{t}_{i}\right)$ is the mathematical derivative of the degradation profile at the inflection point (maximum degradation rate) $\left(h^{-1}\right)$, and $t_{i}$ is the time at the inflection point $(h)$. The $t_{i}$ values were obtained according to the equation reported by Vieira et al. (1997) as follows:

$$
t_{i}=\frac{1}{\lambda}
$$

\subsection{Microbiology}

Ruminal samples used for the quantification of bacteria and protozoa were collected on day 19 of each period, $3 \mathrm{~h}$ after ruminal infusion of supplement. Ciliate protozoa were identified using a Sedgewick-Rafter chamber as described by Dehority (1984), with the modifications suggested by D'Agosto and Carneiro (1999).

Ruminal fluid samples from five steers from the same Latin square were used for the quantification of archaea and bacteria. Total DNA was extracted using a FastDNA ${ }^{\circledR}$ Spin Kit for Soil (MP Biomedicals) according to the manufacturer's instructions.

The relative abundances of of archaea (Denman et al., 2007) and the three cellulolytic bacterial species, namely, $F$. succinogenes (Denman and McSweeney, 2006), R. albus (Mosoni et al., 2007), and R. flavefaciens (Denman and McSweeney, 2006), were determined by qPCR using the standard primers. Data were normalized using the 16S rRNA gene amplified by the total bacterial primer as a "housekeeping gene"(Denman and McSweeney, 2006) and qPCR was performed using an ABI Prism 7500 and SYBR Green (Applied Biosystems ${ }^{\oplus}$ ) technology.

In our previous experiments (Carvalho et al., 2016) we observed a reduction of methane emissions from cattle supplemented with linseed oil. Therefore, we decided to sequence DNA samples of control and linseed oil supplemented groups. Briefly, a library of $16 \mathrm{~S}$ rDNA fragments obtained from the rumen contents was constructed according to the Strategy for Modular Tagged High-Throughput 
Amplicon Sequencing (Cárcer et al., 2011). Gene fragments of 16S rRNA from the samples were amplified by PCR according to (Quince et al., 2011) with the following primers: 515F (5'-GTGNCAGCMGCCGCGGTAA-3') and 926R (5'-CCGYCAATTYMTTTRAGTTT-3'). The PCR was performed under the following conditions: $94^{\circ} \mathrm{C}$ for $2 \mathrm{~min}$; 32 cycles of denaturing at $94{ }^{\circ} \mathrm{C}$ for $10 \mathrm{~s}$, annealing at $57{ }^{\circ} \mathrm{C}$ for $45 \mathrm{~s}$, and extension at $72{ }^{\circ} \mathrm{C}$ for $45 \mathrm{~s}$; and a final extension at $72{ }^{\circ} \mathrm{C}$ for $10 \mathrm{~min}$. The products were cleaned with CIP ExoPCR cleanup protocol, and primers bar codes were applied in the second PCR using the purified product (17 $\mu \mathrm{L})$ of the first PCR. The second PCR was performed under the following conditions: $95^{\circ} \mathrm{C}$ for $2 \mathrm{~min}$; 10 cycles of denaturing at $95{ }^{\circ} \mathrm{C}$ for $10 \mathrm{~s}$, annealing at $55^{\circ} \mathrm{C}$ for $30 \mathrm{~s}$, and extension at $68^{\circ} \mathrm{C}$ for $60 \mathrm{~s}$; and a final extension at $68^{\circ} \mathrm{C}$ for $10 \mathrm{~min}$. All amplicons from different samples were normalized using Quantity One, Bio-Rad Gel Doc 2000 imaging system (Bio-Rad, CA, USA ). Mixed PCR products were isolated from agarose gel and purified using the MinElute kit (Qiagen ${ }^{\circ}$ ). Sequencing was performed on the FLX Roche $454^{\circ}$. Sequences obtained from each sample were processed using the QIIME pipeline v. 1.9.1 (Caporaso et al., 2011). Taxonomic assignment of sequences was performed as operational taxonomic units (OTUs) of 97\% similarity against the Greengenes database (McDonald et al., 2012).

\subsection{Statistical Analysis}

A replicated Latin square $(5 \times 5)$, with five sources of supplement, five experimental periods, and 10 animals was used to evaluate feed intake, digestibility, protozoa count, ruminal parameters, and the kinetics of fibrous particle degradation. The statistical model included treatment as fixed effect (4 degrees of freedom, DF). Steers (4 DF) and periods (4DF) were random effects.

The relative abundances of methanogenic and cellulolytic bacteria were analyzed as a single $5 \times 5$ Latin square with five supplement sources, five animals, and five experimental periods. The statistical model included a treatment (4 DF) as a fixed effect, and steer (4 DF) and period (4 DF) as random effects. Ammonia and VFA concentrations and pH were assessed as repeated effects and the covariance structures selected generated the lowest corrected Akaike information criterion (AICc) and Bayesian information criterion (BIC). Data were subjected to analysis of variance using the PROC MIXED procedure of SAS (2004). When significant, the means between treatments were compared using Tukey's minimum significant difference (i.e., option PDIFF adjust $=$ Tukey of the command LSMEANS). Significance was declared at $P \leq 0.05$.

For the evaluations of transit kinetics and fiber degradation, the lipid sources within each supplement were used as independent variables to interpret the treatment effects. Comparisons among treatments were performed using regression and linear correlation (Myers, 1990). The model parameters were estimated using the Gauss-Newton nonlinear procedure of SAS (2004).

\section{Results}

The intake of DM, pasture DM, OM, CP, and NDF was greater $(P<0.01)$ in the WF than in the groups supplemented with PO, PF, and WS. EE intake was lower $(P<0.01)$ in the WF $(270 \mathrm{~g}$ of EE/day), and it was similar among the animals supplemented with a lipid source (Table 2).

The steers that received the WF treatment had a greater $(P=0.03)$ total apparent digestibility of DM than the animals that received PO. PO supplementation led to lower digestibility of the NDF $(P<0.01)$ than did supplementation with WF, PF, and WS (Table 2).

SFA intake was greater by 44-54\% $(P<0.01)$ in the animals supplemented with PO than in those that received other treatments. The animals supplemented with WS had a greater intake $(P<0.01)$ of UFA, followed by those supplemented with LO and PF. Intake of SFA (capric, lauric, and myristic) was greater $(P<0.01)$ in the PO-supplemented animals. The animals that received PF increased $(P<0.01)$ their stearic and oleic fatty acid intake. The consumption of linoleic acid was greater $(P<0.01)$ in the WS-treated

Table 2

Effects of supplementation with palm oil (PO), linseed oil (LO), protected fat (PF), whole soybeans (WS), and dietary treatment without additional fat (WF) on intake and total apparent digestibility in Nellore steers grazing tropical pasture ${ }^{\mathrm{a}}$.

\begin{tabular}{|c|c|c|c|c|c|c|c|}
\hline & \multicolumn{5}{|c|}{ Supplement } & \multirow[t]{2}{*}{ SEM $^{\mathrm{b}}$} & \multirow[t]{2}{*}{$P$ value } \\
\hline & WF & $\mathrm{PO}$ & LO & $\mathrm{PF}$ & WS & & \\
\hline \multicolumn{8}{|l|}{ Intake, $\mathrm{kg} /$ day } \\
\hline $\mathrm{DM}$ & $8.17 \mathrm{a}$ & $6.54 b$ & $7.46 \mathrm{ab}$ & $6.83 \mathrm{~b}$ & $6.71 b$ & 0.365 & 0.004 \\
\hline Dry matter of forage & $5.26 \mathrm{a}$ & $3.60 \mathrm{~b}$ & 4.49ab & $3.91 b$ & $3.80 \mathrm{~b}$ & 0.352 & 0.002 \\
\hline Organic matter & $7.55 \mathrm{a}$ & $6.08 b$ & $6.90 \mathrm{ab}$ & $6.27 \mathrm{~b}$ & $6.20 \mathrm{~b}$ & 0.328 & 0.004 \\
\hline Crude protein & $1.35 \mathrm{a}$ & $1.14 \mathrm{~b}$ & $1.18 \mathrm{ab}$ & $1.13 \mathrm{~b}$ & $1.11 \mathrm{~b}$ & 0.077 & 0.005 \\
\hline Ether extract & $0.27 \mathrm{~b}$ & $0.46 a$ & $0.43 \mathrm{a}$ & $0.41 \mathrm{a}$ & $0.47 \mathrm{a}$ & 0.022 & $<0.001$ \\
\hline $\mathrm{NDF}$ & $3.38 \mathrm{a}$ & $2.45 b$ & $3.01 \mathrm{ab}$ & $2.61 b$ & $2.60 \mathrm{~b}$ & 0.224 & 0.001 \\
\hline Total apparent digestibility, $\mathrm{g} / \mathrm{kg}$ & - & - & - & - & - & - & - \\
\hline Dry matter & $580 \mathrm{a}$ & $510 \mathrm{~b}$ & $550 \mathrm{ab}$ & $540 \mathrm{ab}$ & $540 \mathrm{ab}$ & 14.0 & 0.030 \\
\hline Organic matter & 600 & 550 & 590 & 580 & 580 & 15.0 & 0.23 \\
\hline Crude protein & 670 & 560 & 550 & 560 & 600 & 41.0 & 0.053 \\
\hline Ether extract & $570 \mathrm{~b}$ & $750 a$ & $700 a$ & $690 a$ & $700 a$ & 22.0 & $<0.001$ \\
\hline $\mathrm{NDF}$ & $500 \mathrm{a}$ & $370 \mathrm{~b}$ & $460 \mathrm{ab}$ & $530 \mathrm{a}$ & $510 \mathrm{a}$ & 27.0 & 0.001 \\
\hline
\end{tabular}

\footnotetext{
${ }^{a}$ Means with a different letter in the same row are significantly different $(P<0.05)$.

b Standard error of mean.
} 
Table 3

Effects of supplementation with palm oil (PO), linseed oil (LO), protected fat (PF), whole soybeans (WS), and dietary treatment without additional fat (WF) on intake and duodenal flow of fatty acids in Nellore steers grazing tropical pasture ${ }^{\mathrm{a}}$.

\begin{tabular}{|c|c|c|c|c|c|c|c|}
\hline & \multicolumn{5}{|c|}{ Supplement } & \multirow[t]{2}{*}{ SEM $^{\mathrm{b}}$} & \multirow[t]{2}{*}{$P$ value } \\
\hline & WF & $\mathrm{PO}$ & LO & $\mathrm{PF}$ & WS & & \\
\hline \multicolumn{8}{|l|}{ Fatty acid intake, g/day } \\
\hline C12:0 (lauric) & $11.8 \mathrm{c}$ & $125.4 \mathrm{a}$ & $13.1 \mathrm{c}$ & $22.9 b$ & $8.70 c$ & 2.10 & $<0.001$ \\
\hline C14:0 (myristic) & $2.7 \mathrm{~b}$ & $40.4 \mathrm{a}$ & $2.3 b$ & $2.02 b$ & $1.90 \mathrm{~b}$ & 0.61 & $<0.001$ \\
\hline C16:0 (palmitic) & 77.5ab & $88.7 \mathrm{a}$ & 76.9ab & $57.6 \mathrm{~b}$ & $55.6 \mathrm{~b}$ & 7.37 & 0.014 \\
\hline C18:0 (stearic) & $18.4 \mathrm{c}$ & $19.9 c$ & $24.5 b c$ & $52.6 \mathrm{a}$ & $31.3 \mathrm{~b}$ & 1.77 & $<0.001$ \\
\hline C18:1 n9,c (oleic) & $91.1 c$ & $113.1 b c$ & $114.2 \mathrm{bc}$ & $176.4 \mathrm{a}$ & $127.4 \mathrm{~b}$ & 7.82 & $<0.001$ \\
\hline C18:2 n6,c (linoleic) & $75.2 \mathrm{~b}$ & $60.9 c$ & $77.5 \mathrm{~b}$ & $85.6 \mathrm{~b}$ & 196.1a & 3.69 & $<0.001$ \\
\hline C18:3 n3 (linolenic) & $7.46 c$ & $5.6 c$ & $118.2 \mathrm{a}$ & $5.10 \mathrm{c}$ & $19.5 \mathrm{~b}$ & 1.52 & $<0.001$ \\
\hline SFAs & $143.1 b$ & $303.1 \mathrm{a}$ & $133.2 b$ & $162.6 \mathrm{~b}$ & $137.6 \mathrm{~b}$ & 10.5 & $<0.001$ \\
\hline UFAs & $131.7 d$ & $146.7 d$ & $279.4 b$ & $238.1 \mathrm{c}$ & $314.9 \mathrm{a}$ & 9.47 & $<0.001$ \\
\hline Fatty acid flow, g/day & - & - & - & - & - & - & - \\
\hline C10:0 (capric) & $0.00 \mathrm{~b}$ & $0.37 \mathrm{a}$ & $0.00 \mathrm{~b}$ & $0.02 b$ & $0.00 \mathrm{~b}$ & 0.038 & 0.008 \\
\hline C12:0 (lauric) & $1.93 \mathrm{~b}$ & $24.5 \mathrm{a}$ & $1.88 \mathrm{~b}$ & $1.42 \mathrm{~b}$ & $1.69 \mathrm{~b}$ & 2.59 & $<0.001$ \\
\hline C14:0 (myristic) & $4.37 \mathrm{~b}$ & $23.3 \mathrm{a}$ & $2.65 b$ & $2.02 b$ & $1.14 \mathrm{~b}$ & 1.81 & $<0.001$ \\
\hline C16:0 (palmitic) & 50.2 & 47.1 & 65.8 & 41.1 & 50.9 & 4.57 & 0.65 \\
\hline C18:0 (stearic) & 148 & 153 & 329 & 184 & 276 & 23.3 & 0.15 \\
\hline C18:1 n11t (vaccenic) & $16.5 b$ & $8.22 b$ & $34.7 \mathrm{a}$ & $16.1 b$ & $7.27 \mathrm{~b}$ & 2.07 & $<0.001$ \\
\hline C18:1 n9.c (oleic) & $34.5 \mathrm{ab}$ & $21.6 \mathrm{~b}$ & $63.4 \mathrm{a}$ & $30.9 b$ & $23.9 b$ & 3.78 & 0.010 \\
\hline C18:2 n6.c (linoleic) & $5.92 b$ & $6.50 \mathrm{~b}$ & $18.6 \mathrm{a}$ & $7.60 \mathrm{~b}$ & $10.1 \mathrm{ab}$ & 1.14 & 0.006 \\
\hline C18:3 n3 (linolenic) & 0.48 & 0.00 & 0.59 & 0.42 & 0.23 & 0.09 & 0.16 \\
\hline Saturated fatty acids & 271 & 236 & 403 & 231 & 328 & 27.1 & 0.35 \\
\hline Unsaturated fatty acids & $58.4 \mathrm{~b}$ & $42.5 b$ & $122 \mathrm{a}$ & $61.1 b$ & $42.7 \mathrm{~b}$ & 7.02 & 0.002 \\
\hline BUFAs $^{c}, \mathrm{~g} / 100 \mathrm{~g}$ & 77.3ab & $77.0 \mathrm{~b}$ & $70.7 \mathrm{~b}$ & $72.9 \mathrm{~b}$ & $85.1 \mathrm{a}$ & 1.10 & 0.001 \\
\hline
\end{tabular}

${ }^{a}$ Means with a different letter in the same row are significantly different $(P<0.05)$.

b Standard error of mean.

${ }^{c}$ Biohydrogenation of total unsaturated $\mathrm{C} 18$ fatty acids.

animals, and the consumption of linolenic acid was greater for the LO-treated animals (Table 3).

PO resulted in greater $(P<0.01)$ flow (g/day) of SFA, such as capric, lauric, and myristic acid, to the duodenum, while the flow of total vaccenic acid was increased $(P<0.01)$ with LO supplementation. The passage of oleic acid was greater $(P=0.01)$ in the animals supplemented with LO than in those supplemented with PO, PF, and WS, but this did not differ from that observed with WF. The flow of linoleic acid was greater in the animals that received LO compared with those fed WF, PO, and PF. The amount of BUFA flowing from the duodenum was greater $(P<0.01)$ for the animals that received WS compared with those that were fed PO, LO, and PF but did not differ from those fed WF (Table 3$)$.

There was no treatment $\times$ time interaction $(P>0.05)$ for ruminal $\mathrm{pH}$ or VFAs; therefore, only the treatment means are reported and discussed. The average ruminal $\mathrm{pH}$ was 6.10. This value was not affected by the treatments $(P=0.47)$. Furthermore, interactions between treatments and sampling times had no effect on the evaluation VFA concentration $(P>0.05)$. The acetate concentration was lower $(P=0.02)$ in the animals supplemented with WS than in those supplemented with PO. In contrast, a greater propionate concentration was observed $(P<0.01)$ in the animals supplemented with PO than in those fed WF, PF, and WS. The total VFA concentration was greater in the animals from the PO group compared with those from the WS group $(P=0.04)$. The animals from the PO and LO groups had lower $(P<0.01)$ acetate: propionate ratio $(\mathrm{A}: \mathrm{P})$ than did those from the other groups $($ Table 4$)$.

The rumen $\mathrm{NH}_{3}{ }^{-} \mathrm{N}$ concentration differed among treatments $(P<0.01)$ and sampling times $(P<0.01)$ and was influenced by

Table 4

Effects of supplementation with palm oil (PO), linseed oil (LO), protected fat (PF), whole soybeans (WS), and dietary treatment without additional fat (WF) on ruminal volatile fatty acid (VFA) composition and $\mathrm{pH}$ in Nellore $(n=10)$ steers grazing tropical pasture ${ }^{\mathrm{a}}$.

\begin{tabular}{|c|c|c|c|c|c|c|c|}
\hline & \multicolumn{5}{|c|}{ Supplement } & \multirow[t]{2}{*}{ SEM $^{\mathrm{b}}$} & \multirow[t]{2}{*}{$P$ value } \\
\hline & WF & $\mathrm{PO}$ & LO & $\mathrm{PF}$ & WS & & \\
\hline $\mathrm{pH}$ & 6.11 & 6.07 & 6.15 & 6.11 & 6.07 & 0.09 & 0.47 \\
\hline Total VFAs, $\mathrm{m} M$ & $120 \mathrm{ab}$ & $124 a$ & $114 \mathrm{ab}$ & $115 \mathrm{ab}$ & $105 b$ & 8.32 & 0.036 \\
\hline Acetate $(\mathrm{mol} / 100 \mathrm{~mol})$ & $67.5 \mathrm{ab}$ & $64.3 \mathrm{~b}$ & $67.2 \mathrm{ab}$ & $67.0 \mathrm{ab}$ & $68.5 a$ & 0.98 & 0.019 \\
\hline Propionate $(\mathrm{mol} / 100 \mathrm{~mol})$ & $20 \mathrm{~b}$ & $24.9 \mathrm{a}$ & $22.4 \mathrm{ab}$ & $21.7 \mathrm{~b}$ & $21.1 b$ & 0.95 & $<0.010$ \\
\hline Butyrate (mol/100 mol) & 12.4 & 10.8 & 10.5 & 11.3 & 10.4 & 0.57 & 0.085 \\
\hline Molar ratio & $3.41 \mathrm{a}$ & $2.90 \mathrm{~b}$ & $3.02 \mathrm{~b}$ & $3.35 \mathrm{a}$ & $3.30 \mathrm{a}$ & 0.11 & $<0.01$ \\
\hline
\end{tabular}

\footnotetext{
${ }^{a}$ Means with a different letter in the same row are significantly different $(P<0.05)$.

b Standard error of mean.
} 
Table 5

Effects of supplementation with palm oil (PO), linseed oil (LO), protected fat (PF), whole soybeans (WS) and dietary treatment without additional fat (WF) on the ruminal ammonia concentration $(\mathrm{mg} / \mathrm{dL})$ in Nellore steers grazing tropical pasture ${ }^{\mathrm{a}}$.

\begin{tabular}{|c|c|c|c|c|c|c|c|}
\hline \multirow[t]{2}{*}{ Time (h) } & \multicolumn{5}{|c|}{ Supplement } & \multirow[t]{2}{*}{ SEM $^{\mathrm{b}}$} & \multirow[t]{2}{*}{$P$ value } \\
\hline & WF & $\mathrm{PO}$ & LO & $\mathrm{PF}$ & WS & & \\
\hline 0700 & 6.76 & 7.18 & 6.5 & 9.00 & 10.06 & 1.18 & 0.20 \\
\hline 1000 & $19.6 \mathrm{~b}$ & $26.1 \mathrm{a}$ & $27.7 \mathrm{a}$ & $26.5 a$ & $12.2 \mathrm{c}$ & 2.43 & $<0.01$ \\
\hline 1300 & $6.96 \mathrm{~b}$ & $17.1 \mathrm{a}$ & 11.8ab & $10.9 \mathrm{ab}$ & $8.12 b$ & 2.37 & $<0.01$ \\
\hline 1600 & $17.2 \mathrm{bc}$ & $26.5 a$ & $24.4 \mathrm{ab}$ & $18.5 \mathrm{abc}$ & $10.9 c$ & 3.68 & $<0.01$ \\
\hline 1900 & 14.2 & 18.8 & 13.9 & 20.5 & 13.3 & 3.86 & 0.41 \\
\hline 2200 & 11.6 & 18.7 & 14.5 & 14.7 & 9.55 & 3.77 & 0.17 \\
\hline
\end{tabular}

${ }^{\text {a }}$ Means with a different letter in the same row are significantly different $(P<0.05)$.

b Standard error of mean.

the interaction between treatment and sampling time $(P<0.01)$. Thus, an analysis was performed using the average value of each supplement group within each sample collection period (Table 5). No differences were observed in the $\mathrm{NH}_{3}{ }^{-} \mathrm{N}$ concentration among the treatments collected at of $0 \mathrm{~h}(P=0.20), 12 \mathrm{~h}(P=0.41)$, or $15 \mathrm{~h}(P=0.17)$. Immediately following the first supplementation $(0700 \mathrm{~h})$, a greater $\mathrm{NH}-\mathrm{N}$ concentration was observed $(P<0.01)$ in the animals from the PO, LO, and PF groups. The WSsupplemented animals had the lowest $\mathrm{NH}_{3}-\mathrm{N}$ concentration $(P<0.01)$ at $0 \mathrm{~h}$. At 13:00 and $1600 \mathrm{~h}$, the $\mathrm{NH}_{3}{ }^{-} \mathrm{N}$ concentration remained higher $(P<0.01)$ in the steers supplemented with $\mathrm{PO}$, but only when compared with those supplemented with WF and WS.

Differences were observed $(P<0.01)$ in the time-dependent rate of the ruminal flow of particles $(\gamma)$. However, no differences $(P=0.88)$ were observed for the time between the application of the external marker and its appearance in the feces $(\tau)($ Table 6$)$. The ruminal flow of particles was slower in the PO and PF groups in contrast to those with WF group, leading to an increase in the average time of retention in the rumen-reticulum.

The common rate of latency and degradation $(\lambda)$ differed $(P<0.01)$ among the treatments (Table 7). Supplementation with PO led to $75 \%$ lower $\lambda$ than WF supplementation.

Transformed values for the total protozoa count were used to quantify the protozoa population. The total protozoa population was reduced by the PO treatment $(P<0.05$; Table 8$)$. With regard to microbial quantification, no effects were observed on relative abundance for populations of Fibrobacter succinogenes $(P=0.53)$ or Ruminococcus flavefaciens $(P=0.46)($ Table 8$)$. A difference in the relative abundance of $R$. albus was only observed between the PO and WS groups $(P=0.04)$, and this proportion was greater in the animals supplemented with WS and lower in those supplemented with PO. The relative proportion of methanogens in samples of ruminal fluid decreased $(P=0.003)$ with PO supplementation.

Sequencing generated 43,483 sequences from which 597 OTUs were identified. The number of sequences and OTUs were not affected by the diet ( $P>0.05$; Table 9). The relative abundance (\%) of members belonging to the bacterial genera Atopobium, Paludibacter, Roseburia, Shuttleworthia, Eubacterium, lactobacillus, and SHD-231 was reduced by the LO treatment $(P<0.05)$. In contrast, the abundance of Prevotella, Fibrobacter, Coprococcus, Lachnospira, Streptococcus, Geobacter, and Pelobacter was greater in the animals supplemented with LO $(P<0.05)$.

\section{Discussion}

In this study, we evaluated the effects of lipid sources with different FA profiles on rumen fermentation, microbial abundance, nutrient utilization, and in the duodenal flow of FA. We hypothesized that lipid protected sources, such as WS and PF or more saturated, as PO would cause less disturbance to ruminal fermentation. LO supplementation would increase the flow of UFA to the

Table 6

Estimated parameters of fibrous particle kinetics in grazing steers supplemented with palm oil (PO), linseed oil (LO), protected fat (PF), whole soybeans (WS) and the dietary treatment without additional fat (WF).

\begin{tabular}{|c|c|c|c|c|c|}
\hline \multirow[b]{2}{*}{ Supplements } & \multicolumn{5}{|c|}{ Parameter $^{\mathrm{a}}$} \\
\hline & $\mathrm{Z}$ & $\gamma$ & $\tau$ & MRTR & MRTT \\
\hline WF & 11.7 & 0.032 & 5.75 & 62.7 & 68.4 \\
\hline $\mathrm{PO}$ & 10.51 & 0.019 & 6.95 & 108 & 115 \\
\hline LO & 11.12 & 0.032 & 5.90 & 62.9 & 68.8 \\
\hline $\mathrm{PF}$ & 11.52 & 0.020 & 6.74 & 85.5 & 92.2 \\
\hline WS & 12.01 & 0.030 & 6.47 & 60.6 & 67.1 \\
\hline$P$-value & - & $<0.001$ & 0.88 & - & - \\
\hline
\end{tabular}

${ }^{\mathrm{a}} \mathrm{Z}=$ parameter without biological meaning (ppm x h); $\gamma=$ time-dependent rate parameter related to the rumen flow of fibrous particles ( $\mathrm{h}^{-1}$ ); $\tau=$ time of intestinal transit $(\mathrm{h})$; MRTR = mean retention time in the rumen; (h) MRTT = mean retention time in the gastrointestinal tract $(\mathrm{h})$. 
Table 7

Effects of supplementation with palm oil (PO), linseed oil (LO), protected fat (PF), whole soybeans (WS), and dietary treatment without additional fat (WF) on the estimation of parameters of neutral detergent fiber degradation in Nellore steers grazing tropical pasture.

\begin{tabular}{|c|c|c|c|c|}
\hline \multirow[t]{2}{*}{ Supplements } & \multicolumn{4}{|c|}{ Parameter $^{\mathrm{a}}$} \\
\hline & B & $\mathrm{U}$ & $\lambda$ & LAG \\
\hline WF & 52.8 & 47.2 & 0.060 & 4.70 \\
\hline $\mathrm{PO}$ & - & - & 0.021 & 13.4 \\
\hline LO & - & - & 0.054 & 5.03 \\
\hline $\mathrm{PF}$ & - & - & 0.056 & 4.86 \\
\hline WS & - & - & 0.058 & 5.22 \\
\hline$P$-value & - & - & $<0.001$ & $<0.001$ \\
\hline
\end{tabular}

${ }^{\mathrm{a}} \mathrm{B}=$ potentially degradable fraction of NDF (\%); $\mathrm{U}=$ undegradable fraction of NDF (\%); $\lambda=$ common rate of lag and degradation $\left(\mathrm{h}^{-1}\right)$; LAG $=$ discrete lag $(\mathrm{h})$.

duodenum and decrease intake due to impaired rumen fermentation and animal metabolism. However, PO reduced fiber degradation and feed intake. The supplement with linseed oil did not affect feed intake and increased the amount of UFA reaching the duodenum.

The increase in DM and nutrient intake observed in animals in the WF group are in accordance with the results of previous studies (Bateman and Jenkins, 1998; Shingfield et al., 2010; Wanapat et al., 2011), which also demonstrated a reduction in feed intake due to the inclusion of FA in ruminant diets. The decreased intake may be attributed to a greater proportion of UFA in the blood serum, which activates the satiety center of the hypothalamus (Allen, 2000).

UFAs have a high potential to negatively affect rumen fermentation (Jenkins, 1993). However, among the lipid sources evaluated in the current study, WS and LO increased UFA intake without affecting DM or NDF digestibility. Fiorentini et al. (2014) did not detect a reduction in DMI in cattle fed a diet with a forage: concentrate ratio of 60:40 and $50 \mathrm{~g} / \mathrm{kg}$ PF in the concentrate DM, and they attributed the lower impact on intake to protection conferred by calcium salts, which decreased the negative effects of UFAs on microbial metabolism.

The utilization of saturated oils may attenuate the negative effects of FA on ruminal fermentation (Wanapat et al., 2011), because they are made of molecules that react less with microbial membranes than UFA (Harfoot and Hazlewood, 1997). Nonetheless, the lipid sources used in this study, such as PO, contain an abundance of medium-chain fatty acids (MCFAs), such as lauric and myristic fatty acids, which can reduce the abundance of some microbial strains (Soliva et al., 2004a,b) and may decrease fiber fermentation in the rumen. The reduction in NDF digestibility due to PO inclusion with respect that observed with WF inclusions corroborates the $8 \mathrm{~h}$ increase in latency and the 42 and 65\% reductions in ruminal particle flow $(\gamma)$ and rate of latency and degradation, respectively. Thus, although suppression of the cellulolytic bacterial population was expected, only a numerical reduction in the Ruminococcus albus proportion was observed, which did not significantly differ from that of the control group. In many cases, the abundance of cellulolytic bacteria are not always attributed to NDF degradability and correlations among community abundance and functionality in microbial ecology have not been studied in depth (Mosoni et al., 2007).

It is possible that the high proportions of dietary fiber attenuated the negative effects of supplemental fat, particularly in the animals supplemented with lipid sources containing high levels of UFA (LO and WS). High-fiber diets are capable of increasing the raters of lipolysis and biohydrogenation (Jenkins, 1993) and decreasing the levels of free UFA in the ruminal environment, thereby reducing the negative effects of lipids on microorganisms (Broudiscou et al., 1994; Bateman and Jenkins, 1998). Bensalem et al. (1993) evaluated the inclusion of colza oil in the diets of cows fed with corn silage or hay, reported negative effects on feed intake and digestibility when animals where fed with high-fiber and low-starch diets.

Although the inclusion of UFA did not decrease the cellulolytic bacterial population, the methanogen population was lower in the animals supplemented with LO and PF. The dissociation of calcium salts from PF might occur at $\mathrm{pH} 6.11$ to a minor extent. The greater concentration in the lauric acid (C12:0) in the PF than in the WF diet would induce membrane damage in the methanogens

Table 8

Effects of supplementation with palm oil (PO), linseed oil (LO), protected fat (PF), whole soybeans (WS), and dietary treatment without additional fat (WF) on the relative abundance of archaea, Ruminococcus albus, Fibrobacter succinogenes, Ruminococcus flavefaciens and the protozoa count in Nellore steers grazing tropical pasture ${ }^{\mathrm{a}}$.

\begin{tabular}{|c|c|c|c|c|c|c|c|}
\hline & \multicolumn{5}{|c|}{ Supplement } & \multirow[t]{2}{*}{$\mathrm{SEM}^{\mathrm{b}}$} & \multirow[t]{2}{*}{$P$ value } \\
\hline & WF & $\mathrm{PO}$ & LO & $\mathrm{PF}$ & WS & & \\
\hline Archaea & $1.92 \mathrm{a}$ & $0.27 c$ & $0.98 \mathrm{~b}$ & $1.16 \mathrm{~b}$ & $1.27 \mathrm{ab}$ & 0.20 & $<0.01$ \\
\hline Ruminococcus albus & $0.72 \mathrm{ab}$ & $0.33 b$ & $0.64 \mathrm{ab}$ & $0.85 \mathrm{ab}$ & $1.00 \mathrm{a}$ & 0.19 & 0.04 \\
\hline Fibrobacter succinogenes & 0.026 & 0.017 & 0.021 & 0.059 & 0.021 & 0.023 & 0.53 \\
\hline Ruminococcus flavefaciens & 0.13 & 0.039 & 0.069 & 0.11 & 0.14 & 0.06 & 0.46 \\
\hline Protozoa $\left(\log _{10}\right)$ & $6.13 a$ & $5.13 b$ & $5.58 \mathrm{ab}$ & $6.08 \mathrm{a}$ & $5.87 a$ & 0.19 & $<0.01$ \\
\hline
\end{tabular}

\footnotetext{
${ }^{\text {a }}$ Means with a different letter in the same row are significantly different $(P<0.05)$.

b Standard error of mean.
} 
Table 9

Effects of supplementation with linseed oil (LO) and dietary treatment without additional fat (WF) on microbial diversity.

\begin{tabular}{|c|c|c|c|c|c|}
\hline Phylum & Genus & WF & LO & SEM $^{\mathrm{a}}$ & $P$ value \\
\hline \multirow[t]{2}{*}{ Actinobacteria } & Atopobium & 1.00 & 0.50 & 0.010 & 0.011 \\
\hline & Arthrobacter & 0.00 & 0.10 & 0.001 & 0.14 \\
\hline \multirow[t]{2}{*}{ Bacteroidetes } & Prevotella & 28.4 & 34.1 & 5.29 & 0.014 \\
\hline & Paludibacter & 0.20 & 0.00 & 0.001 & 0.004 \\
\hline Fibrobacteres & Fibrobacter & 0.10 & 1.10 & 0.001 & 0.001 \\
\hline \multirow[t]{12}{*}{ Firmicutes } & Ruminococcus & 12.4 & 11.9 & 2.51 & 0.20 \\
\hline & Butyrivibrio & 10.8 & 11.0 & 2.68 & 0.25 \\
\hline & Pseudobutyrivibrio & 1.20 & 0.80 & 0.074 & 0.35 \\
\hline & Roseburia & 0.70 & 0.40 & 0.008 & 0.003 \\
\hline & Coprococcus & 0.40 & 0.60 & 0.091 & 0.021 \\
\hline & Lachnospira & 0.08 & 0.28 & 0.012 & $<0.001$ \\
\hline & Shuttleworthia & 0.42 & 0.12 & 0.03 & 0.001 \\
\hline & Eubacterium & 0.39 & 0.28 & 0.012 & $<0.001$ \\
\hline & Moryella & 0.11 & 0.12 & 0.04 & 0.64 \\
\hline & Selenomonas & 8.19 & 9.04 & 1.82 & 0.34 \\
\hline & Streptococcus & 0.10 & 0.97 & 0.008 & 0.029 \\
\hline & lactobacillus & 0.70 & 0.30 & 0.005 & 0.044 \\
\hline \multirow[t]{2}{*}{ Proteobacteria } & Geobacter & 0.30 & 0.70 & 0.028 & 0.041 \\
\hline & Pelobacter & 0.01 & 0.10 & 0.003 & 0.026 \\
\hline Chloroflexi & SHD-231 & 0.50 & 0.10 & 0.012 & 0.005 \\
\hline Spirochaetes & Treponema & 0.08 & 0.09 & 0.011 & 0.74 \\
\hline Synergistetes & TG5 & 0.10 & 0.10 & 0.037 & 0.84 \\
\hline Tenericutes & Bulleidia & 0.20 & 0.20 & 0.017 & 0.74 \\
\hline \multirow[t]{3}{*}{ Euryarchaeota } & Methanosphaera & 2.18 & 2.20 & 0.81 & 0.62 \\
\hline & Methanobrevibacter & 13.4 & 14.5 & 2.49 & 0.37 \\
\hline & Thermoplasmates $^{c}$ & 1.40 & 0.93 & 0.035 & 0.49 \\
\hline
\end{tabular}

${ }^{\text {a }}$ Standard error of mean.

(Zhou et al., 2013) and reduces its abundance in the rumen. Martin et al. (2010) performed meta-analysis of data collected from 20 studies and concluded that supplementation with high levels of polyunsaturated fatty acids (linolenic and linoleic acids) decreases the rate of production of $\mathrm{CH}_{4}$ to as low as $4.1 \%$ and $4.8 \%$ (per percent unit of lipid added), respectively.

High levels of MCFAs, such as lauric and myristic acids presents in the PO supplement can be toxic to ruminal bacteria and archaea (Soliva et al., 2004a,b). Dissociation of MCFAs in bacterial cells has been reported as an antimicrobial mechanism (Goel et al., 2009). The 3:1 ratio of C12:C14 observed in the PO-treated animals represented a 7\% lower relative proportion compared to than that in the LO-treated animals, corroborating the results of Soliva et al. (2004a,b), who found 60\% suppression of the methanogen proportion and a $70 \%$ reduction in the production of $\mathrm{CH}_{4}$ due to the addition of lauric and myristic acids at a $4: 1$ ratio in vitro.

The greater propionate concentration and lower acetate: propionate ratio in the animals fed with PO and LO indicates that the activity of microbial propionate producers was higher than that of fibrolytic bacteria. The enhanced molar proportion of propionate and decreased C2:C3 ratio due to the inclusion of lipid sources can explain the decreased methanogen proportion by limiting $\mathrm{H}_{2}$ availability for their metabolism $(P<0.05$; Table 8$)$, which is in agreement with the results reported by Bateman and Jenkins (1998).

The results of the microbial diversity analysis (Table 9), indicate the methanogenic species did not differ between animals receiving linseed oil supplement and the control. The methanogenic groups identified in this study were: Methanobrevibacter, Methanosphaera, and Thermoplasmates (Rumen Cluster C), with a high predominance of Methanobrevibacter ( $>98 \%$ ). Janssen and Kirs (2008) compared the diversity of methanogenic microbes in animals worldwide, receiving different diets and concluded that the predominant groups were Methanobrevibacter, Methanomicrobium, and Thermoplasmatales (Rumen Cluster C).

Significant differences were observed in bacterial diversity with LO supplementation from that in the control $(P<0.05)$. These results corroborate those reported by Belenguer et al. (2010) who observed changes in the microbial community of animals supplemented with soybean and fish oils. As discussed, UFAs have a negative effect on parts of the rumen microbial population, which being a dynamic system can modify the growth of other organisms.

The Prevotella genus was the most abundant in our study, with 28 and $34 \%$ for control and linseed oil supplements, respectively. Prevotella is the predominant genus in the ruminal diversity analysis (Belenguer et al., 2010; Callaway et al., 2010 and Wu et al., 2012). The high genetic and functional diversity of Prevotella is shown by the metabolism of proteins in the synergism with cellulolytic species (Wu et al., 2012). The increase in Prevotella may be an opportunistic response to the addition of oil because it may have hindered growth of other bacteria (McCann et al., 2014). LO supplementation reduced the Selenomonas population and it is consistent with the methane reduction presented in our performance paper (Carvalho et al., 2016). Some strains of Selenomonas reduce fumarate- using $\mathrm{H}_{2}$ as the final electron donor, which might compete with methanogens for $\mathrm{H}_{2}$ (Asanuma et al., 1999).

Butyrivibrio has been described as the main genus involved in the isomerization and reduction during biohydrogenation (Jenkins et al., 2008). However, other microorganisms in addition to Butyrivibrio are involved in PUFA biohydrogenation. In particular, in vivo 
studies on rumen bacterial diversity in cows and ewes suggested that B. fibrisolvens and B. proteoclasticus do not play a dominant role in the rumen lipid metabolism and that other as-yet-uncultivated bacteria phylogenetically classified as Prevotella, Lachnospinaceae incertae sedis, unclassified Bacteroidales, Clostridiales and Ruminococcaceae might be more relevant (Boeckaert et al., 2008; Belenguer et al., 2010; Huws et al., 2011; Castro-Carrera et al., 2014). The proportion of OTU's from Butyrivibrio was not altered by LO addition in the diet, the observed value of $3.8 \%$ of the total bacterial population was similar to that observed by Callaway et al. (2010) and lower than that reported by Wu et al. (2012), who found 4.3 and $12.9 \%$, respectively. The growth of some species of Butyrivibrio is inhibited by linoleic acid (Jenkins et al., 2008). Therefore, the rumen population changes with LO supplementation may have occurred among species, and not been identified at the genus level, which is responsible for most isomerization and reduction reactions in the biohydrogenation (Jenkins et al., 2008).

An adequate $\mathrm{NH}_{3}-\mathrm{N}$ level in the ruminal environment is crucial for optimization of the fermentative process. In this study, the $\mathrm{NH}_{3}-\mathrm{N}$ level remained above the optimum level of $10 \mathrm{mg} / \mathrm{dL}$ recommended by Leng (1990) and Sampaio et al. (2010). All the diets used in this study, including that without lipid inclusion, contained similar amounts of protein. However, the soybean treatment did not contain urea, which explains the small variation observed in the ammonia concentration throughout the day in the animals from this group. Reports in the literature on the effects of dietary lipids to diets on the $\mathrm{NH}_{3}-\mathrm{N}$ level remain contradictory in that a decrease (Wanapat et al., 2011), an increase (Homem Junior et al., 2010) and a lack of effect (Shingfield et al., 2010; Toral et al., 2010) have all been reported.

A decrease in ruminal protozoa is often observed as a consequence of fat inclusion in ruminant diets (Martinele et al., 2008; Wanapat et al., 2011). Furthermore, the mechanisms underlying the impaired growth of these microorganisms due to FA are similar to those described for bacteria (Jenkins, 1993), including a disturbance in membrane structure, which hinder microbial nutrient uptake (Maia et al., 2007). In our study, the supplementation with PO (rich in MCFA) had a more negative effect on protozoa population than LO (rich in PUFA) when compared with WF supplement. Patra and Yu (2013) evaluated in vitro two different oils and observed a greater decrease of protozoa abundance with coconut oil (CO) than fish oil (FO) and they attributed this toxic effect on protozoa abundance to the greater solubility of MCFA in CO than long chain fatty acid found in FO.

The increase in EE digestibility detected in the animals fed the lipid-supplemented diets is in accordance with the results reported by Manso et al. (2006) and Pavan and Duckett (2007).The greater coefficient of digestibility observed in the fat-supplemented animals may be explained by the greater digestibility of added fat than digestibility of FA in feed particles and by the dilution of endogenous lipids. The SFA proportion in the duodenum was greater than the amount of FA consumed, demonstrating the effects of ruminal biohydrogenation.

The high duodenal flow of vaccenic acid detected in the animals supplemented with LO may have occurred due to the high levels of linoleic acid and its precursors present in this lipid source. Several studies have demonstrated that linolenic and linoleic acids inhibit the growth of Butyrivibrio proteoclasticus, which is responsible for the reduction of vaccenic acid to stearic acid (Maia et al., 2007), thus, increasing the duodenal flow of C18:1 trans-11. The vaccenic acid flowing from the duodenum can be transformed in animal tissues to conjugated linoleic acid cis-9 trans-11 (CLA) through the action of $\Delta$ 9-desaturase (Griinari and Bauman, 1999).

The biohydrogenation ratio of 18C UFA for the PF was expected to be lower than the value of $72 \%$ observed in our study. However, previous studies have demonstrated that the ruminal protection of FA by calcium salts is inconsistent. Klusmeyer and Clark (1991) have reported a rate of protection of 50\% against ruminal biohydrogenation of FA by soybean calcium salts. Similarly, Lundy et al. (2004) included $27.5 \mathrm{~g} / \mathrm{kg}$ calcium salt from soybean oil in the diets of dairy cows and observed biohydrogenation values of 77.9 and $92.2 \%$ for 18:1 (n9) and 18:2 (n6), respectively. According to Jenkins and Bridges (2007), results regarding the use of protected fat are inconsistent, and it offers limited ruminal protection. However, protected fat may be advantageous compared with non-protected fat by increasing the flow of UFA and reducing the risk of digestive disorders.

The greater BUFA concentration in the animals fed the WS-supplemented diet may have occurred as a consequence of the slow release of oil due to the physical characteristics of soybean grain (Palmquist and Jenkins, 1980). When the consumption of UFA is increased (linseed oil), the biohydrogenation ability of ruminal microorganisms may be reduced, leading to greater intestinal absorption of UFA (Beam et al., 2000). The greater ruminal escape of linoleic and vaccenic acids (CLA precursor) resulting from diets containing LO, demonstrates their potential for promoting postruminal deposition desirable UFA in meat and milk.

\section{Conclusions}

Linseed oil, protected fat and soybean grain can be used as supplements for grazing cattle without affecting fiber degradation. The inclusion of palm oil decreases feed intake, total tract NDF digestibility, the transit of particles in the rumen, and fiber degradation. Nonetheless, palm oil, linseed oil and protected fat may reduce the proportion of methanogens in the rumen. The inclusion of linseed oil increases the flow of vaccenic acid and UFA flow to the duodenum, demonstrating a potential way of enhancing beneficial FA in meat.

\section{Conflicts of Interest}

None.

\section{Acknowledgments}

The authors would like to thank the São Paulo Research Foundation (FAPESP- Fundação de Amparo à Pesquisa do Estado de São 


\section{Paulo) process number 09/07314-5 and Bellman Nutrição Animal for their financial support.}

\section{References}

Aldrich, C.G., Merchen, N.R., Drackley, J.K., 1995. The effect of roasting temperature applied to whole soybeans on site of digestion by steers: I. organic matter, energy, fiber, and fatty acid digestion. J. Anim. Sci. 73, 2120-2130.

Allen, M.S., 2000. Effects of diet on short-term regulation of feed intake by lactating dairy cattle. J. Dairy Sci. 83, 1598-1624.

Association of official analytical chemists, 1990. Official methods of analysis, 15th ed. AOAC, Arlington, VA.

Asanuma, N., Iwamoto, M., Hino, T., 1999. Effect of the addition of fumarate on methane production by ruminal microorganisms in vitro. J. Dairy Sci. 82, 780-787.

Bateman, H.G., Jenkins, T.C., 1998. Influence of soybean oil in high fiber diets fed to nonlactating cows on ruminal unsaturated fatty acids and nutrient digestibility. J. Dairy Sci. 81, 2451-2458.

Beauchemin, K.A., Kreuzer, M., O’Mara, F., McAllister, T.A., 2008. Nutritional management for enteric methane abatement: a review. Aust. J. Exp. Agr. 48, 21-27.

Beam, T.M., Jenkins, T.C., Moate, P.J., Kohn, R.A., Palmquist, D.L., 2000. Effects of amount and source of fat on the rates of lipolysis and biohydrogenation of fatty acids in ruminal contents. J. Dairy Sci. 83, 2564-2573.

Belenguer, A., Toral, P.G., Frutos, P., Hervas, G., 2010. Changes in the rumen bacterial community in response to sunflower oil and fish oil supplements in the diet of dairy sheep. J. Dairy Sci. 93, 3275-3286.

Bensalem, H., Krzeminski, R., Ferlay, A., Doreau, M., 1993. Effect of lipid supply on in-vivo digestion in cows - comparison of hay and corn-silage diets. Can. J. Anim. Sci. 73, 547-557.

Boeckaert, C., Vlaeminck, B., Fievez, V., Maignien, L., Dijkstra, J., Boon, N., 2008. Accumulation of trans C18:1 fatty acids in the rumen after dietary algal supplementation is associated with changes in the Butyrivibrio community. Appl. Environ. Microb. 74, 6923-6930.

Broudiscou, L., Pochet, S., Poncet, C., 1994. Effect of linseed oil supplementation on feed degradation and microbial synthesis in the rumen of ciliate-free and refaunated sheep. Anim. Feed. Sci. Technol. 49, 189-202.

Callaway, T.R., Dowd, S.E., Edrington, T.S., Anderson, R.C., Krueger, N., Bauer, N., Kononoff, P.J., Nisbet, D.J., 2010. Evaluation of bacterial diversity in the rumen and feces of cattle fed different levels of dried distillers grains plus solubles using bacterial tag-encoded FLX amplicon pyrosequencing. J. Anim. Sci. 88, 3977-3983.

Caporaso, J.G., Lauber, C.L., Walters, W.A., Berg-Lyons, D., Lozupone, C.A., Turnbaugh, P.J., Fierer, N., Knight, R., 2011. Global patterns of 16S rRNA diversity at a depth of millions of sequences per sample. Proc. Natl. Acad. Sci. USA 108, 4516-4522.

Carvalho, I.P.C., Fiorentini, G., Berndt, A., Castagnino, P.S., Messana, J.D., Frighetto, R.T.S., Reis, R.A., Berchielli, T.T., 2016. Performance and methane emissions of Nellore steers grazing tropical pasture supplemented with lipid sources. Rev. Bras. Zootec. 45, 760-767.

Casali, A.O., Detmann, E., Valadares Filho, S.d.C., Pereira, J.C., Henriques, L.T., Freitas, S.G., Paulino, d.M.F., 2008. Influence of incubation time and particles size on indigestible compounds contents in cattle feeds and feces obtained by in situ procedures. Rev. Bras. Zootec. 37, $335-342$.

Cárcer, D.A., Denman, S.E., McSweeney, C., Morrison, M., 2011. Strategy for modular tagged high-throughput amplicon sequencing. Appl. Environ. Microb. 77, 6310-6312.

Castro-Carrera, T., Toral, P.G., Frutos, P., McEwan, N.R., Hervas, G., Abecia, L., Pinloche, E., Girdwood, S.E., Belenguer, A., 2014. Rumen bacterial community evaluated by 454 pyrosequencing and terminal restriction fragment length polymorphism analyses in dairy sheep fed marine algae. J. Dairy Sci. $97,1661-1669$.

Dehority, B.A., 1984. Evaluation of subsampling and fixation procedures used for counting rumen protozoa. Appl. Environ. Microb. $48,182-185$.

D’Agosto, M., Carneiro, M.E., 1999. Evaluation of lugol solution used for counting rumen ciliates. Rev. Bras. Zool. 16, $725-729$.

Denman, S.E., McSweeney, C.S., 2006. Development of a real-time PCR assay for monitoring anaerobic fungal and cellulolytic bacterial populations within the rumen. FEMS Microbiol. Ecol. 58, 572-582.

Denman, S.E., Tomkins, N.W., McSweeney, C.S., 2007. Quantitation and diversity analysis of ruminal methanogenic populations in response to the antimethanogenic compound bromochloromethane. FEMS Microbiol. Ecol. 62, 313-322.

Duckett, S.K., Gillis, M.H., 2010. Effects of oil source and fish oil addition on ruminal biohydrogenation of fatty acids and conjugated linoleic acid formation in beef steers fed finishing diets. J. Anim. Sci. 88, 2684-2691.

Ellis, W.C., Matis, J.H., Hill, T.M., 1994. Methodology for estimating digestion and passage kinetics of forages. In: Fahey, G.C., Collins, M., Mertens, D.R., Moser, L. (Eds.), Forage quality, evaluation, and utilization. American Society of Agronomy, Madison, WI, pp. 682-756.

Fenner, H., 1965. Method for determining total volatile bases in rumen fluid by steam distillation. J. Dairy Sci. 48, $249-251$.

Fiorentini, G., Carvalho, I.P.C., Messana, J.D., Castagnino, P.S., Berndt, A., Canesin, R.C., Frighetto, R.T.S., Berchielli, T.T., 2014. Effect of lipid sources with different fatty acid profiles on the intake, performance, and methane emissions of feedlot Nellore steers. J. Anim. Sci. 92, 1613-1620.

Folch, J., Lees, M., Stanley, G.H.S., 1957. A simple method for the isolation and purification of total lipides from animal tissues. J. Biol. Chem. 226, 497-509.

Goel, G., Arvidsson, K., Vlaeminck, B., Bruggeman, G., Deschepper, K., Fievez, V., 2009. Effects of capric acid on rumen methanogenesis and biohydrogenation of linoleic and alpha-linolenic acid. Animal 3, 810-816.

Grainger, C., Beauchemin, K.A., 2011. Can enteric methane emissions from ruminants be lowered without lowering their production? Anim. Feed Sci. Technol. 166-67, 308-320.

Griinari, J.M., Bauman, D.E., 1999. Biosynthesis of conjugated linoleic acid and its incorporation into meat and milk in ruminants. In: Yurawecz, M.P., Mossoba, M.M., Kramer, J.K.C., Nelson, G., Pariza, M.W. (Eds.), Advances in conjugated linoleic acid research Vol. 1. AOCS Press, Champaign, Il, pp. 180-200.

Gudla, P., AbuGhazaleh, A.A., Ishlak, A., Jones, K., 2012. The effect of level of forage and oil supplement on biohydrogenation intermediates and bacteria in continuous cultures. Anim. Feed Sci. Technol. 171, 108-116.

Harfoot, C.G., Hazlewood, G.P., 1997. Lipid metabolism in the rumen. In: Hobson, P.N., Stewart, C.S. (Eds.), The rumen microbial ecosystem. Blackie Academic and Professional Press, London, UK, pp. 382-419.

Harvatine, K.J., Allen, M.S., 2006. Effects of fatty acid supplements on ruminal and total tract nutrient digestion in lactating dairy cows. J. Dairy Sci. 89, 1092-1103. Hess, B.W., Moss, G.E., Rule, D.C., 2008. A decade of developments in the area of fat supplementation research with beef cattle and sheep. J. Anim. Sci. 86, E188-E204.

Homem Junior, A.C., Ezequiel, J.M.B., Fávaro, V.R., Oliveira, P.S.N., D’Aurea, A.P., Santos, V.C., Gonçalves, J.S., 2010. Ruminal fermentation of sheep fed highconcentrated diet containing sunflower grains or protected fat. Arq. Bras. Med. Vet. Zootec. 62, 144-153.

Huws, S.A., Kim, E.J., Lee, M.R.F., Scott, M.B., Tweed, J.K.S., Pinloche, E., Wallace, R.J., Scollan, N.D., 2011. As yet uncultured bacteria phylogenetically classified as Prevotella, Lachnospiraceae incertae sedis and unclassified Bacteroidales, Clostridiales and Ruminococcaceae may play a predominant role in ruminal biohydrogenation. Environ. Microbiol. 13, 1500-1512.

Janssen, P.H., Kirs, M., 2008. Structure of the archaeal community of the rumen. Appl. Environ. Microb. 74, 3619-3625.

Jenkins, T.C., 1993. Lipid metabolism in the rumen. J. Dairy Sci. 76, 3851-3863.

Jenkins, T.C., Bridges, W.C., 2007. Protection of fatty acids against ruminal biohydrogenation in cattle. Eur. J. Lipid Sci. Technol. 109, 778-789.

Jenkins, T.C., Wallace, R.J., Moate, P.J., Mosley, E.E., 2008. Board-invited review: recent advances in biohydrogenation of unsaturated fatty acids within the rumen microbial ecosystem. J. Anim. Sci. 397-412.

Johnson, A.D., 1978. Sample preparation and chemical analysis of vegetation. In: Manejte, L.T. (Ed.), Measurement of grassland vegetation and animal production. Commonwealth Agricultural Bureaux, Aberystwyth, UK, pp. 96-102.

Knapp, J.R., Laur, G.L., Vadas, P.A., Weiss, W.P., Tricarico, J.M., 2014. Invited review: enteric methane in dairy cattle production: quantifying the opportunities and impact of reducing emissions. J. Dairy Sci. 97, 3231-3261.

Klusmeyer, T.H., Clark, J.H., 1991. Effects of dietary fat and protein on fatty acid flow to the duodenum and in milk produced by dairy cows. J. Dairy Sci. 74, 3055-3067.

Kramer, J.K.C., Fellner, V., Dugan, M.E.R., Sauer, F.D., Mossoba, M.M., Yurawecz, M.P., 1997. Evaluating acid and base catalysts in the methylation of milk and rumen 
fatty acids with special emphasis on conjugated dienes and total trans fatty acids. Lipids 32, 1219-1228.

Kucuk, O., Hess, B.W., Rule, D.C., 2004. Soybean oil supplementation of a high-concentrate diet does not affect site and extent of organic matter, starch, neutral detergent fiber, or nitrogen digestion, but influences both ruminal metabolism and intestinal flow of fatty acids in limit-fed lambs. J. Anim. Sci. 82, $2985-2994$.

Leng, R.A., 1990. Factors affecting the utilization of 'poor-quality' forages by ruminants particularly under tropical conditions. Nutr. Res. Rev. 3, $277-303$.

Ludden, P.A., Kucuk, O., Rule, D.C., Hess, B.W., 2009. Growth and carcass fatty acid composition of beef steers fed soybean oil for increasing duration before slaughter. Meat Sci. 82, 185-192.

Lundy, F.P., Block, E., Bridges, W.C., Bertrand, J.A., Jenkins, T.C., 2004. Ruminal biohydrogenation in holstein cows fed soybean fatty acids as amides or calcium salts. J. Dairy Sci. 87, 1038-1046.

McCann, M., Loor, J., Wickersham, T., 2014. High-throughput methods redefine the rumen microbiome and its relationship with nutrition and metabolism. Bioinform. Biol. Insights 109.

McDonald, D., Price, M.N., Goodrich, J., Nawrocki, E.P., DeSantis, T.Z., Probst, A., Andersen, G.L., Knight, R., Hugenholtz, P., 2012. An improved greengenes taxonomy with explicit ranks for ecological and evolutionary analyses of bacteria and archaea. ISME J. 6, 610-618.

Maia, M.R., Chaudhary, L.C., Figueres, L., Wallace, R.J., 2007. Metabolism of polyunsaturated fatty acids and their toxicity to the microflora of the rumen. Antonie Van Leeuwenhoek 91, 303-314.

Manso, T., Castro, T., Mantecon, A.R., Jimeno, V., 2006. Effects of palm oil and calcium soaps of palm oil fatty acids in fattening diets on digestibility, performance and chemical body composition of lambs. Anim. Feed. Sci. Technol. 127, 175-186.

Martin, C., Morgavi, D.P., Doreau, M., 2010. Methane mitigation in ruminants: from microbe to the farm scale. Animal 4, $351-365$.

Martinele, I., Eifert, E.d.C., Lana, R., Arcuri, d.P.P.B., D’Agosto, M., 2008. Effect of monensin and soybean oil on rumen ciliate protozoa and correlation between protozoa with ruminal fermentation and digestive parameters. Rev. Bras. Zootec. 37, 1129-1136.

Mertens, D.R., 2002. Gravimetric determination of amylase-treated neutral detergent fibre in feeds with refluxing in beaker or crucibles: collaborative study. J. AOAC Int. 85, 1217-1240.

Montgomery, S.P., Drouillard, J.S., Nagaraja, T.G., Titgemeyer, E.C., Sindt, J.J., 2008. Effects of supplemental fat source on nutrient digestion and ruminal fermentation in steers. J. Anim. Sci. 86, 640-650.

Mosoni, P., Chaucheyras-Durand, F., Bera-Maillet, C., Forano, E., 2007. Quantification by real-time PCR of cellulolytic bacteria in the rumen of sheep after supplementation of a forage diet with readily fermentable carbohydrates: effect of a yeast additive. J. Appl. Microbiol. 103, $2676-2685$.

Myers, R.H., 1990. Classical and modern regression with applications. Duxbury Press, Boston, Mass.

Oliveira, S.G., Berchielli, T.T., Pedreira, M.D., Primavesi, O., Frighetto, R., Lima, M.A., 2007. Effect of tannin levels in sorghum silage and concentrate supplementation on apparent digestibility and methane emission in beef cattle. Anim. Feed Sci. Technol. 135, 236-248.

Otaru, S.M., Adamu, A.M., Ehoche, O.W., Makun, H.J., 2011. Effects of varying the level of palm oil on feed intake, milk yield and composition and postpartum weight changes of Red Sokoto goats. Small Rumin. Res. 96, 25-35.

Palmquist, D.L., Jenkins, T.C., 1980. Fat in lactation rations: review. J. Dairy Sci. 63, 1-14.

Patra, A.K., Yu, Z., 2013. Effects of coconut and fish oils on ruminal methanogenesis, fermentation, and abundance and diversity of microbial populations in vitro. J. Dairy Sci. 96, 1782-1792.

Pavan, E., Duckett, S.K., 2007. Corn oil supplementation to steers grazing endophyte-free tall fescue. II. Effects on longissimus muscle and subcutaneous adipose fatty acid composition and stearoyl-CoA desaturase activity and expression. J. Anim. Sci. 85, 1731-1740.

Quince, C., Lanzen, A., Davenport, R.J., Turnbaugh, P.J., 2011. Removing noise from pyrosequenced amplicons. BMC Bioinformatics 12.

Sampaio, C.B., Detmann, E., Paulino, M.F., Valadares Filho, S.C., de Souza, M.A., Lazzarini, I., Paulino, P.V., de Queiroz, A.C., 2010. Intake and digestibility in cattle fed low-quality tropical forage and supplemented with nitrogenous compounds. Trop. Anim. Health. Pro. 42, 1471-1479.

Santos, S.A., Valadares, S.D., Detmann, E., Valadares, R.F.D., Ruas, J.R.D., Amaral, P.D., 2011. Different forage sources for F1 Holstein x Gir dairy cows. Livest. Sci. $142,48-58$.

Santana, M.C.A., Vieira, B.R., Costa, D.F., Dian, P.H.M., Fiorentini, G., Canesin, R.C., Pereira, G.T., Reis, R.A., Berchielli, T.T., 2015. Source and frequency of dry season lipid supplementation of grazing, finishing cattle. Anim. Prod. Sci. 55, 745-751.

SAS Institute, 2004. SAS/STAT 9.1 User's Guide Version 9 1.3. SAS Inst. Inc, Cary NC.

Shingfield, K.J., Lee, M.R.F., Humphries, D.J., Scollan, N.D., Toivonen, V., Reynolds, C.K., Beever, D.E., 2010. Effect of incremental amounts of fish oil in the diet on ruminal lipid metabolism in growing steers. Brit. J. Nutr. 104, 56-66.

Soliva, C.R., Meile, L., Cieslak, A., Kreuzer, M., Machmuller, A., 2004a. Rumen simulation technique study on the interactions of dietary lauric and myristic acid supplementation in suppressing ruminal methanogenesis. Brit. J. Nutr. 92, 689-700.

Soliva, C.R., Meile, L., Hindrichsen, I.K., Kreuzer, M., Machmuller, A., 2004b. Myristic acid supports the immediate inhibitory effect of lauric acid on ruminal methanogens and methane release. Anaerobe 10, 269-276.

Toral, P.G., Shingfield, K.J., Hervas, G., Toivonen, V., Frutos, P., 2010. Effect of fish oil and sunflower oil on rumen fermentation characteristics and fatty acid composition of digesta in ewes fed a high concentrate diet. J. Dairy Sci. 93, 4804-4817.

Van Milgen, J., Murphy, M.R., Berger, L.L., 1991. A compartmental model to analyze ruminal digestion. J. Dairy Sci. 74, 2515-2529.

Vega, A., Gasa, J., Castrillo, C., Guada, J.A., 1998. Passage through the rumen and the large intestine of sheep estimated from faecal marker excretion curves and slaughter trials. Brit. J. Nutr. 80, 381-389.

Vieira, R.A., Pereira, J.C., Malafaia, P.A.M., Queiroz, A.C., 1997. The influence of elephant-grass (Pennisetum purpureum Schum., Mineiro variety) growth on the nutrient kinetics in the rumen. Anim. Feed Sci. Technol. 67, 151-161.

Zhou, X., Meile, L., Kreuzer, M., Zeitz, J.O., 2013. The effect of saturated fatty acids on methanogenesis and cell viability of Methanobrevibacter ruminantium. Archaea.

Wanapat, M., Mapato, C., Pilajun, R., Toburan, W., 2011. Effects of vegetable oil supplementation on feed intake, rumen fermentation, growth performance, and carcass characteristic of growing swamp buffaloes. Livest. Sci. 135, 32-37.

Wu, S., Ransom, L., Baldwin, R.L., Li, W., Li, C., Connor, E.E., Li, R.W., 2012. The bacterial community composition of the bovine rumen detected using pyrosequencing of 16S rRNA genes. Metagenomics 1, 1-11.

Yang, S.L., Bu, D.P., Wang, J.Q., Hu, Z.Y., Li, D., Wei, H.Y., Zhou, L.Y., Loor, J.J., 2009. Soybean oil and linseed oil supplementation affect profiles of ruminal microorganisms in dairy cows. Animal 3, 1562-1569. 